\title{
Brand strategies development through sales promotion and endorsement of Small and Medium Enterprises (SME) in West Java Indonesia
}

Desenvolvimento de estratégias de marca por meio de promoção de vendas e endosso de Pequenas e Médias Empresas (PME) em Java Ocidental na Indonésia

Desarrollo de estrategias de marca a través de la promoción de ventas y el respaldo de Pequeñas y Medianas Empresas (PYME) en West Java Indonesia

Received: 06/14/2021 | Reviewed: 06/16/2021 |Accept: 06/23/2021 | Published: 07/08/2021

\author{
Syahnaz Zun Nur'ain Mauligita \\ ORCID: https://orcid.org/0000-0002-4037-9129 \\ School of Business and Management, Institut Teknologi Bandung, Indonésia \\ E-mail: syahnaz_zun@sbm-itb.ac.id \\ Nila Armeilia Windasari \\ ORCID: https://orcid.org/0000-0001-6298-9553 \\ School of Business and Management, Institut Teknologi Bandung, Indonésia \\ E-mail: nila.armelia@sbm-itb.ac.id
}

\begin{abstract}
Not all business in the market get customer attentions as they deserve, especially for Small Medium Enterprise (SME). It sparks fierce competition between SME to stand out from rivals in the market. Sales promotion is known as one of the most effective method which influence sales volume, especially for SME's market. The second strategy is having endorsement from a third-party. Previous studies have identified impact of monetary promotion through online and in-store strategy to build strong brand identity without, and so as endorsement. However, there is still inadequate understanding of branding development particularly what specific promotions and endorsement works better for SME, as previous research are mostly based on multinational or big firms which have different characteristics with SME. Therefore, this paper examine the impact of two types of promotions, which are: monetary (vs non-monetary) promotion and celebrity (vs.non-celebrity) endoresement into better customer perceptions about SMEs' product and brand.
\end{abstract}

Keywords: Celebrity endorsement; Non-celebrity endorsement; Monetary promotion; Non-monetary promotion; Sales promotion; Small medium enterprise (SME).

\section{Resumo}

Nem todas as empresas do mercado recebem a atenção do cliente como ele merece, especialmente para Pequenas e Médias Empresas (PMEs). Isso desencadeia uma competição acirrada entre as PME para se destacar dos rivais no mercado. A promoção de vendas é reconhecida como um dos métodos mais eficazes para influenciar o volume de vendas, especialmente para o mercado de PMEs. A segunda estratégia é ter o endosso de um terceiro. Estudos anteriores identificaram o impacto da promoção monetária por meio de estratégias online e na loja para construir uma identidade de marca forte sem e, portanto, como endosso. No entanto, ainda há uma compreensão inadequada do desenvolvimento da marca, especialmente quais promoções e endosso específicos funcionam melhor para as PME, uma vez que as pesquisas anteriores são baseadas principalmente em empresas multinacionais ou grandes que têm características diferentes com as PME. Portanto, este artigo examina o impacto de dois tipos de promoções, que são: promoção monetária (versus não monetária) e endosso de celebridade (versus não celebridade) em melhores percepções do cliente sobre os produtos e marcas das PMEs.

Palavras-chave: Endosso de celebridades; Endosso de não celebridades; Promoção monetária; Promoção não monetária; Promoção de vendas; Pequena e média empresa (PME).

\section{Resumen}

No todas las empresas del mercado reciben la atención de los clientes como se merecen, especialmente las pequeñas y medianas empresas (PYME). Desencadena una feroz competencia entre las PYME para diferenciarse de sus rivales en el mercado. La promoción de ventas es conocida como uno de los métodos más efectivos que influyen en el volumen de ventas, especialmente para el mercado de las PYME. La segunda estrategia es contar con el respaldo de un tercero. Estudios anteriores han identificado el impacto de la promoción monetaria a través de la estrategia en línea y en la tienda para construir una identidad de marca sólida sin y, por lo tanto, respaldo. Sin embargo, todavía hay una 
comprensión inadecuada del desarrollo de la marca, en particular qué promociones y patrocinios específicos funcionan mejor para las PYME, ya que las investigaciones anteriores se basan principalmente en empresas multinacionales o grandes que tienen características diferentes con las PYME. Por lo tanto, este documento examina el impacto de dos tipos de promociones, que son: promoción monetaria (versus no monetaria) y endosamiento de celebridades (versus no celebridades) en mejores percepciones de los clientes sobre el producto y la marca de las PYMES.

Palabras clave: Apoyo de famosos; Respaldo de no celebridades; Promoción Monetaria; Promoción no monetaria; Promoción de ventas; Pequeña y mediana empresa (PYME).

\section{Introduction}

As a developing country, the economy in Indonesia cannot be separated from the contribution of the micro, small and medium enterprises (SMEs) sector. Data from the Ministry of Cooperatives and Micro, Small and Medium Enterprises shows that the contribution of the SMEs sector to Indonesia's Gross Domestic Product from 2017 to 2019 has remained consistent at $60 \%$, even in 2020 it is predicted to increase to 61\% (Ukmindonesia.id, 2020). The position of SMEs in the national economy has an important and strategic role, where the existence of SMEs is quite dominant in the Indonesian economy. It is important for the government to continue to support SMEs through strengthening, so that their role as pillars in building the nation's economy can run optimally (Sarfiah et al., 2019). According to the Minister of Finance of the Republic of Indonesia, Sri Mulyani Indrawati at the World Islamic Economic Forum in 2016, said that SMEs have proven to be a strong sector when economic shocks occur. SMEs are also the backbone of the economy because almost $99 \%$ of business activities in Indonesia and SMEs have absorbed 107.6 million Indonesian workers and contributed $60.6 \%$ to Indonesia's gross domestic product (Nurcahya \& Majapahit, 2018).

In the midst of the development of Micro, Small and Medium Enterprises (SMEs), in early 2020 an event emerged that shocked the world and had a significant impact on developments in all sectors, namely the Covid-19 Pandemic. Where since its initial appearance in Wuhan City, Hubei, China, various sectors have been paralyzed due to the dangers posed by this virus, including the economy. When viewed from this case, various ways to prevent the spread of the Covid-19 virus are conducting social distancing or PSBB (Large-Scale Social Restrictions), or even lockdowns in several countries. In Indonesia, the government has tried these efforts which have a direct impact on the drastic decline of the SME economy, because people's purchasing power is decreasing day by day (finance.detik.com, 2020).

Empowering SMEs in the midst of these problems and also the high competition makes SMEs have to increase and expand their marketing area. This needs to be done to increase the bargaining power of SMEs themselves, especially so that they can compete with foreign products that are increasingly flooding the manufacturing industry in Indonesia (Sedyastuti, 2018). Therefore, strategies to increase customer awareness and brands of SMEs become important topic to be discussed.

One way of promoting products at SMEs is advertising on various social media and offline. Advertising is a persuasive communication medium designed to generate responses and help achieve marketing objectives or objectives. This is in line with the development of the digital world used to develop online marketing. One of the ways in which the advertisements are made can attract the attention of consumers is by using endorsements. Endorser selection must be considered. There are many factors that determine the success or failure of a product, but the use of endorsements can indeed be one of the factors, especially its nature as a driving force for consumers to buy (Shouman, 2020).

The use of endorsements is a creative strategy in advertising that is used so that people can form perceptions about a product or brand by associating endorsers with their products and creating brand awareness in the community as users of these products. The use of celebrities as endorsers is expected to be able to give a positive impression on products and businesses that are owned and can be seen by various groups because the use of celebrities is in the spotlight by various parties. Celebrity 
endorsers have a big role in helping to sustain marketing activities, both globally and locally. Research tends to show that using a Celebrity Endorser has the most positive effects (Lea-Greenwood, 2012). There are not a few costs incurred by the company, when the company wants to hire a celebrity as its endorser. Building a relationship between endorsers and brand equity is an important thing for advertising managers and marketing managers to do, it aims to justify the expenditure allocated for advertising that uses celebrities as endorsers.

In addition to the use of creative advertising such as endorsements, SMEs generally establish various strategies to increase consumer attractiveness to buy, namely by sales promotions. According to Kotler and Armstrong (2008), sales promotion consists of short-term incentives to encourage the purchase or sale of a product or service. In this case, SMEs use one of the sales promotion tools in the form of discounting, giving discounts, giving bonuses, gifts and others as an effort to encourage consumers to buy SME's products. This is of course done to make consumers feel like coming back because they are satisfied with being given more service. When consumers get good service quality and profit on sales promotions that have been given by the company, consumers will feel satisfied (Kotler \& Armstrong, 2008). According to Schnaars in (Tjiptono \& Anastasia, 2016) states that the purpose of a business is to create satisfied customers.

The problem that occurs in SMEs is generally the consumer's perception of the quality offered by SMEs who think that buying goods at malls, well-known companies or imported goods is considered to be of better quality than SMEs at quite competitive prices (Ekonomibisnis.com, 2018). In addition, perceived quality of Indonesian's SMEs is at an absolute advantage compared to similar products, or considered as good quality. High quality will lead to consumer intention to buy a product or service. Purchases are made at the expense of a certain amount of money that consumers expect to get a certain quality of the product concerned. The higher the quality of the product that is perceived by consumers, the higher the consumer's purchase intention is (Bimantari, 2019). Perceptions of quality in good SMEs can be optimized through marketing expansion either by endorsement or by sales promotion.

In addition to perceptions of the quality of SME products, consumers also feel fear at the risk of products offered by SMEs. As with products that are less competitive with imported goods or companies that already have names. In addition to the risks to consumers, there are several SME risks that are experienced by many developing countries including Indonesia, among others, are 1) lack of raw materials so that they must be imported from other countries; 2) marketing; 3) capital: 4) availability of energy, infrastructure and information. In addition, non-physical problems such as high inflation, skills, and labor regulations are also often experienced by ASEAN countries, including Indonesia (Sudaryanto \& Wijayanti, 2014). In this case, increasing marketing needs to be done to reduce the risk of bad perception of SMEs in the eyes of consumers by endorsement and sales promotion.

The importance of endorsement and sales promotion has an effect on consumer relationships with brands from SMEs or self-brand connections (Sari \& Dewi, 2019). Self-brand connection is the formation of a self-connection with a brand that is already known as a personal brand connection, which occurs when consumers and user personalities have a close relationship to a specific brand and then they insert it into their own identity (Chaplin \& John, 2005). Furthermore, Chaplin and John (2005) explain that this process begins with brand compatibility which is similar to a self-concept called self-image or productimage congruity theory.

This study use SMEs in West Java as the subject of the research. West Java is one of the provinces that has the most SMEs in Java on 2015 (Databoks.katadata.co.id, 2016; BPS, 2016). The large number of SMEs in West Java is even able to absorb a fairly large workforce. SMEs is one of the most appropriate places to accommodate workers who do not have high skills. SE2016 data provides information that SMEs have absorbed more than 9 million workers, or about three-quarters of the non-agricultural workforce in West Java (West Java Central Statistics Agency, 2016). Thus, we consider this as a valid reason 
for studying the impact of sales promotion and endorsement in West Java SMEs.

\section{Literature Review}

\section{Small and Medium-sized Enterprise}

Small and medium-sized enterprise (SMEs) have ability to move and decide quicky, according to that, SMEs need to recognize the strategy to maintain their sustainability. SMEs have big influence to country GDP because it has the ability to move and decide quickly, the dynamic characteristic of SME and also the ability to innovate (Mujahid \& Noman, 2018). It is important, especially for small company to know their ability and how they could use it to sustain in the business, but most of SME think that their company did not big enough to perform data and usually relay on some big customer (Loucks et al., 2010).

One of the strategies that SMEs can use to perform their business and increasing their sales is toward sales promotion. Sales promotion can be considered as an effective and efficient tool for increasing sales, otherwise it can be a loss to the brand image at the same time based on price (Mussol et al., 2019). Several literatures have investigated regarding the roles of sales promotion and the relationships with brand strategy. The impact of sales promotion towards brand seems to have diverse influence across types of sales promotion (Buil et al., 2013; Mussol et al., 2019) and different customer segment (ValetteFlorence et al., 2011).

\section{Celebrity Endorsement}

According to Shimp (Shimp, 2010) celebrity endorsers are advertisements that use famous people or figures (public figures) in supporting an advertisement. So, celebrity endorser is a promotion carried out by the company by issuing products through advertising media and using a celebrity as a supporter of the ad. An endorser must have characters that match the product, so that the message is conveyed properly. Today, many companies are interested in marketing their products using a celebrity endorser because they are considered more efficient.

According to Schiffman and Kanuk (2010), advertisers use a person as an attraction to communicate with the market they want to target. The influence of celebrity endorsers is very significant because it is proven that there are many celebrity endorsers in social media, because of their achievements in a field and can convey informative advertising messages that influence and attract consumers.

In doing an endorsement, a celebrity endorser has the following dimensions (Shimp, 2010):

1. Trustworthiness. Refers to the honesty, integrity, and believability of a source. Endorser trustworthiness simply reflects the fact that prospective endorser of a brand varies in the degree to which audience members have faith in what they have to say.

2. Expertise. Refers to the knowledge, experience, or skill possessed by an endorser as they relate to the endorser brand.

3. Attractiveness. Physical attractiveness refers to the trait of being regarded as pleasant to look at in terms of particular group's concept of attractiveness.

4. Respect. Refers to an endorser who is admired and respected by consumers for his personal qualities and accomplishments.

5. Similarity. An important attribute that easier for consumers to relate to an endorser who has the same characteristics as the consumer 


\section{Non-Celebrity Endorsement}

An advertisement that uses the appeal of someone who is satisfied is called a common man approach (Schiffman \& Kanuk, 2010). The advantage of common man attractiveness is demonstrating to a prospective consumer that someone like them uses and is satisfied with the advertised product or service. Many of the television commercials show people or families who are similar to consumers solving their problems with the advertised product or service. These types of commercials are known as slice of life commercials because they focus on real-life situations that viewers can identify with. Therefore, using non-celebrity or general public is also beneficial to create sense of common interest and closeness with customer's profile.

\section{Monetary Sales-Promotion}

Monetary promotions, or price promotions, are the deals which permit the consumer to get a product at a smaller price, thereby attracting the consumer by offering an opportunity of price saving. The function of monetary promotions is not narrowed to price saving; but also offers benefits like higher product quality and shopping convenience to consumers (Chandon et al., 2000). Task-focused consumers are attracted to monetary promotions (Butter et al., 2015) Researchers found that monetary promotion is better in comparison to non-monetary promotions (Alvarez \& Rodolvo, 2005). According to Chandon et al. (2000), monetary promotion is useful for the utilitarian product while (Kwok and Uncles, 2005) suggest that monetary promotion is preferred for all product types. Therefore, eventhough there is no evidence showing the effectiveness of monetary promotions to SMEs, it is still worthwile to be explored further.

\section{Non-monetary Sales Promotion}

Some sales promotion presents non-monetary benefits like providing gifts, bonus, chances of winning contests, sweepstake, etc., on purchasing a product. Many researchers recommended this kind of promotion because it is not having any harmful impact on the brand value of a product; in fact, it is helpful in enhancing the brand value of the product. In the longrun perspective, non-monetary promotion is considered more favorable compared to monetary promotions (Yi \& Yoo, 2011). Non-monetary promotions never spoil the brand image and may even assist in creating one. Non-monetary promotions make a positive impact on quality perception (Buil et al., 2013). Premiums (non-monetary) are more efficient than price discounts at small benefit levels (Palazon \& Elena, 2009).

\section{Perceived Quality}

In marketing, perception is more important than reality, because perspective affects the actual behavior of consumers. People can have different perceptions of the same object because of three processes of understanding: selective attention, selective distortion, and selective retention.

According to Suryani (2013), consumers' perceptions of quality will directly or indirectly provide an assessment of the services they have purchased or consumed. This is in line with what was stated by Tjiptono and Diana (2016) that the perception of quality is a consumer assessment of the superiority of the product as a whole. This evaluation is carried out based on an overall assessment of what was received and experienced which was then compared with what was expected. Perceived quality is a decision and perception about the overall superiority of a product or service when compared to others. Products or services that have absolute advantages and are also not owned by similar products or services can be said to have a good quality perception. Perceived quality variable measurement indicators in this study were carried out by adopting indicators based on the opinion of Zeithaml in Nasreen (2015), namely consumer evaluation of the quality of the product concerned, which consists of the following: 
Product benefit function. The value of the benefits of the product which usually only ignores the attributes related to the product attributes, this type of attribute shows that the physical composition of a product is very influential in determining the performance and appearance of the product.

The ingredients for the products of the brand. The materials used to make the product, whether using quality ingredients or not. The colour of the product brand. Ensure that the colours used in the manufacture of the product are of good quality. A brand is a durable product. Brand ensures that the product offered is a product that has high durability. The brand consists of various models. The models offered by the product are varied so that consumers can more freely choose. The style of the brand is always attractive. Brand attaches importance to styles that attract consumers' attention and the latest styles

\section{Perceived of Product Risk}

Perceived risk is defined as the uncertainty faced by consumers when they cannot predict the consequences when making a purchase decision. There are two dimensions of important points in the definition of this risk perception, namely uncertainty and consequences. This definition emphasizes that consumers are affected by the risk they perceive, regardless of whether the risk actually exists or not. Risks that do not exist in consumer perceptions will not affect consumer behaviour (Schiffman \& Kanuk, 2010).

The indicators of risk perception consist of: Financial risk means losing an amount of money during a transaction; Product risk means the possibility of a mismatch in receipt of products purchased through SMEs; Functional risk means malfunction of products purchased through SMEs; Security risk means the possibility of theft of personal information during transactions and The risk of losing time means spending a lot of time in making transactions (Vijayasarathy \& Jones, 2000).

\section{Self-Brand Connection}

According to Escalas (2004), the formation of a meaningful and strong bond between the brand and the identity of the consumer is referred to as a self-brand. Meanwhile, forming a relationship with a brand is known as a personal brand. In a selfbrand connection, in general, if consumers feel that they are in accordance with a brand, then the brand will become their identity (Chaplin \& John, 2005). Sprott (Razmus \& Laguna, 2019) introduced Brand Engagement with Self Concept (BESC), which is building brand engagement with self-concept, referring to the tendency of consumers to use brands as part of their self-scheme. However, the self-brand connection is conceptually different from BESC. Self-brand connection captures brandspecific consumers to form "self".

According to Dviwedi (2015) self-brand connection is a self-brand relationship as the formation of a strong and meaningful bond between certain brands and consumer self-identities.

\section{Hypotheses Development}

After structurally reviewing several pieces of literature, this section exposes the potential relationship among the reviewed variable and develop several research hypotheses.

Despite the extensive literature focused on brand equity, how SMEs marketing strategies through sales promotion or endorsement and the relation between them there is little no research on sales promotion and endorsement impact consumer buying intention especially in SMEs. SMEs owner who are planning to develop their strategy and wide their market target lacks the knowledge to take decision in what strategy they must use to achieve the goals. This research aims to fulfil the gap by contributing to marketing strategy; sales promotion and endorsement especially in SMEs and by providing marketers and SMEs owner with relevant managerial insight. 
According to Suryani (2013), the perception of the quality of consumers will directly or indirectly provide an assessment of the services they have purchased or consumed. Consumers who have seen the quality of the products the company offers will generally make repeat purchases. Some consumers admit that good product quality is due to promotion as a marketing strategy through both celebrity endorsement and sales promotion. Perceptions of consumer quality in products are caused by differences between celebrity endorsement and non-celebrity endorsement, according to Shouman's research (2020) which shows that consumers consider the use of celebrity endorsements on social media to be unreliable and help them remember the brand or product better and in addition, there is research that shows that there are differences in perceptions of product quality as seen from promotions through sales promotions (Kuo \& Nakhata, 2016) shows that there are differences in perceived quality by using celebrity endorsement and sales promotion, where the results of the study show that small discounts are enough to increase consumer purchase intention for quality products, but when the time to buy is long, small discounts will not be enough unless the agreement. Both of the studies not explain a comparison endorsement and sales promotion.

H1a: Celebrity endorsement have higher perceived quality (compared to non-celebrity endorsement)

H1b: Monetary sales promotion have higher perceived quality (compared to non-monetary sales promotion)

In summary, monetary promotions are the ones that have a price value implicit to consumer, whereas non-monetary have a gift associated with them. Both types of promotions can include a special offer for a given product. However, in the case of a price promotion, this offer would constitute an extra package of the given product (e.g. buy two get 10\%off), whereas an offer for a different product or service tied to the given product (e.g. buy 5 products free calendar) can be considered a nonmonetary promotion. Following this, monetary promotions are more associated with utilitarian benefits (i.e.: saving money), whereas non-monetary are associated to hedonic benefits (i.e.: receiving an enjoyable gift). Furthermore, this research also highlights two type of endorsement; celebrity endorsement and non-celebrity endorsement. Endorsement gives access to advertisement to broader the target. Because endorsement has specific meanings consist with the endorsers. From this aspect, celebrities' suits endorsement better than non-celebrity because they have broader range of followers, they can deliver meanings and colour of the products better than non-celebrity because they are more competent as public figure (Johansson and Bozan, 2017). But sometime, consumer think that celebrity endorsers are script and not even tried the product and they were more belief if someone who already purchased the product before have an actual review about the product. There is research that shows that there are differences in product risk perceptions on promotion using celebrity endorsement and noncelebrity endorsement, namely research conducted by Syekh (2017) which shows that there is a significant and positive influence of customer brand awareness, customer interaction, brand reputation and image on overall purchasing product of SME brands and Francis \& Yaz danifard (2013) which shows that the customer perception and attitude towards the celebrities also has an influence in whether the brand is truly to be followed by consumers for brand recall, or just another ploy to gain more sales. Whereas studies that show a difference are research conducted by Sinha (2017) and Gumliel \& Herstein (2011) with monetary has an influence in consumer attitudes towards perceived of product risk.

H2a: Celebrity endorsement have higher perceived of product risk (compared to non-celebrity endorsement) $\mathrm{H} 2 \mathrm{~b}$ : Monetary sales promotion have higher perceived of product risk (compared to non-monetary sales promotion)

The previous literature evaluates non-monetary promotions frequently as more positively related to buying intention than monetary promotions, and celebrity endorsement are more effective than non-celebrity endorsement. In this research we try to analysed which one of this four promoting strategy that more suitable and essential for SMEs on perceived quality, perceived of risk, and self-brand connection to catch consumer buying intention. 
There is research that shows that there are differences in perceptions of self-brand connection in promotion using celebrity endorsement and non-celebrity endorsement, namely research conducted by Shouman (2020) which shows that there are differences in self-brand awareness in celebrity endorsement and other promotion, where consumers find the use of celebrity endorsement on social media believable and helps them better remember a brand or a product and Shaikh (2017) shows that there is a significant and positive influence of customer brand awareness, customer involvement, brand reputation and image on overall consumer purchasing behavior of SME brands.

Whereas on monetary and non-monetary, research that shows a difference is research conducted by Senra (Senra, 2017) that overall monetary promotions were found to result in higher brand equity than non-monetary promotions. This was verified for both new and mature products. Nevertheless, both types of promotions are beneficial when contrasted with the situation of no promotion in contrast to having no promotion.

Following this, we developed the following hypothesis:

H3a: Celebrity endorsement have higher perceived of self-brand connection (compared to non-celebrity endorsement)

H3b: Monetary sales promotion have higher perceived of self-brand connection (compared to non-monetary sales promotion).

Research model can be seen in figure below:

Figure 1. Research model.

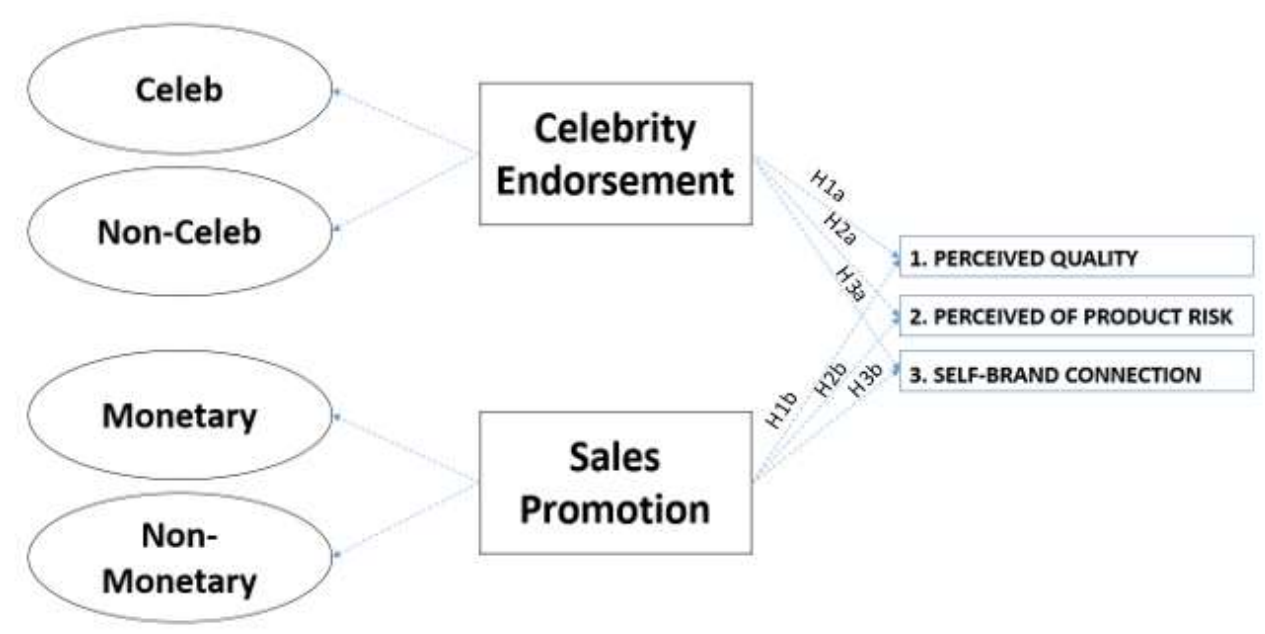

Source: Own study.

\section{Research Method}

This study aims to determine and test whether it is better to use monetary or non-monetary sales promotion and celebrity or non-celebrity endorsement to promote SME products in West Java. Therefore, this type of research is quantitative research and the methods used are experimental survey. Quantitative methods can be interpreted as a research method based on the philosophy of positivity, used to research on certain populations or samples, data collection using questionnaire, data analysis is quantitative or statistical, with the aim of testing the predetermined hypothesis (Sugiyono, 2016).

According to Sugiyono (2016), comparative research is a study that compares between variables.The sampling technique in this study is probability sampling, which is a sampling technique that provides equal opportunities for each 
population to be selected as a sample (Sugiyono, 2016). This is because the number of SMEs in West Java is already known. So, the researchers took the sample by simple random sampling. Simple random sampling considers all samples in similar conditions, namely SMEs in West Java. The number of samples was set at 150 samples.

The questionnaire is using survey random scenario and manipulation check questions (e.g., Have you ever seen a commercial with a celebrity as the star of the product?) to measure if the dependent variable really had an impact on the participants, the example of the survey random scenario can be seen below on Figure 2.

Figure 2. Example of survey random scenario.

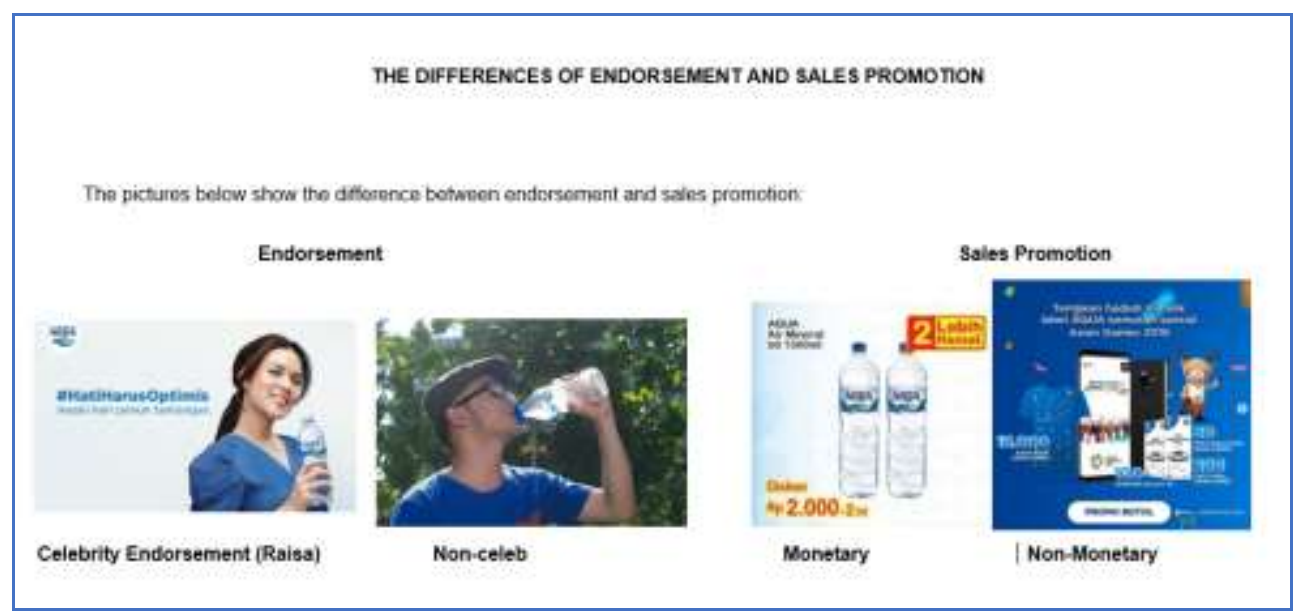

Source: Own study.

Based on the figure above, there are difference of endorsement and sales promotion. Edorsement divided into celebrity endorsement which makes famous figure to promote their product and non celebrity endorsement use non-famous people and focusing on the content of promotion. While sales promotion divided into monetary promotion and non-monetary promotion.

\section{Results and Discussions}

Based on 150 distributed questionnaires, it can be seen that all respondents in this study were consumers of SME products in West Java with 87 female respondents with a percentage of 58\% and $42 \%$ with 63 men. Most of the respondents were in the age range 25-34 years, as many as 45 people (45\%). While the least is in the age range over 45 years. Thus, in this case it shows that the answers from the respondents are those of productive age. It shows that consumers buy very diverse types of products in SMEs including clothing, namely 32 people (21,3\%), food and beverages as many as 48 people (32\%), beauty and body care as many as 27 people (18\%), equipment household as many as 33 people (22\%), other types of products as many as 10 people $(6,67 \%)$. Based on these results, it is known that the types of products most often purchased by consumers in SMEs are food and beverage products, namely 48 people (32\%). Meanwhile, the lowest was other products, which consist of 10 people $(6,67 \%)$.

\section{Two Way ANOVA Analysis}

The ANOVA test was taken by statistical analysis of mean and standard deviation of perceived quality, perceived of product risk and self brand connection. The analysis can be seen on the table below: 
Table 1. Mean and Standard Deviation of Perceived Quality, Perceived of Product Risk and Self-Brand Connection

\begin{tabular}{|l|l|l|l|}
\hline & $\mathbf{N}$ & Mean & Std. Deviation \\
\hline The Average of PQ & $\mathbf{1 5 0}$ & $\mathbf{3 , 8 8 9}$ & $\mathbf{0 , 7 8 2}$ \\
\hline The Average of PR & 150 & $\mathbf{4 , 0 6 8}$ & $\mathbf{0 , 7 2 2}$ \\
\hline The average of SB & 150 & $\mathbf{4 , 1 1 3}$ & $\mathbf{0 , 7 1 9}$ \\
\hline
\end{tabular}

Source: Own study.

Based on the table above, the average of PQ has mean of 3,889 and Standard deviation of 0,782. the average of PR has mean 4,068 and standard deviation of 0,722. While the average of SB obtain the mean of 4,113 and standard deviation of 0,719 .

\section{Result}

To find out the result of test between subjects effect of perceived quality on twi different kind of endorsement can be seen in the table below:

Table 2. Test of Between-Subjects Effects of Perceived Quality (Endorsement).

\section{PQ Endorsement}

Dependent Variable:Perceived Quality
\begin{tabular}{|l|r|r|r|r|}
\hline & & & \multicolumn{2}{|c|}{$95 \%$ Confidence Interval } \\
\cline { 4 - 5 } & & & & \\
PQ Endorsement & Mean & Std. Error & Lower Bound & Upper Bound \\
\hline Celeb Endrosement & 4.210 & .037 & 4.137 & 4.283 \\
Non-Celeb Endorsement & 3.523 & .075 & 3.376 & 3.670 \\
\hline
\end{tabular}

Source: Own study.

Based on the table above, it can be indicated that celebrity endorsement has higher mean and lower error compared to non-celeb endorsement.

Table 3. Test of Between-Subjects Effects of Perceived Quality (Sales Promotion).

\section{PQ Sales Promotion}

Dependent Variable:Perceived Quality

\begin{tabular}{|c|c|c|c|c|}
\hline \multirow{2}{*}{$\begin{array}{l}\text { PQ Sales } \\
\text { Promotion }\end{array}$} & \multirow[b]{2}{*}{ Mean } & \multirow[b]{2}{*}{ Std. Error } & \multicolumn{2}{|c|}{ 95\% Confidence Interval } \\
\hline & & & Lower Bound & Upper Bound \\
\hline Monetary & 4.052 & .075 & 3.904 & 4.200 \\
\hline Non-Monetary & 3.681 & .036 & 3.610 & 3.753 \\
\hline
\end{tabular}

Source: Own study. 
Based on the table above, it can be indicated that monetary promotion has higher mean and higher std.error compared to non monetary promotion.

Figure 3. Perceived Quality Endorsement Chart.

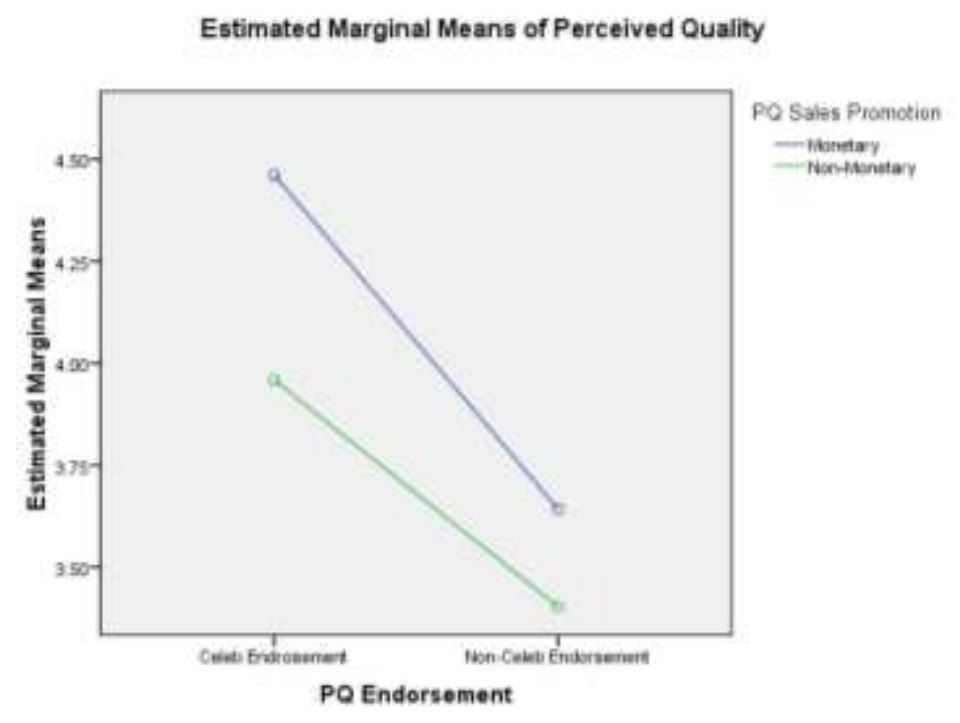

Source: Own study.

Based on the figure 3 above, it can be seen that Participants who receive celebrity endorsement have higher perceived quality than non-celebrity endorsement $($ Mceleb $=4,210$ and Mnon-celeb=3,523; $F(1,149)=68,114, p<0,005)$ while participants of monetary sales promotion have higher than non-monetary sales promotion (Msalesprom=4,052 and Mnon-salesprom= 3,$681 ; \mathrm{F}(1,149)=19,983, \mathrm{p}<0,005$

Two-way Anova was conducted with perceived quality as dependent variable and celebrity endorsement (celeb vs non-celeb) and sales promotion (monetary vs non-monetary) as independent variables. This reaffirms the experimental results. Thus, H1a is supported which shows that consumers tend to buy products with celebrity endorsement related to perceived quality as a marketing strategy for MSME products in West Java. And besides, H1b is also accepted because perceived quality monetary significantly higher than perceived quality non-monetary.

The results of this study are supported by research conducted by Shaikh (Shaikh \& Mazhar, 2017), Haron, et al (Haron, 2013), Nakhata (Kuo \& Nakhata, 2016), Farm, et al (Fam et al., 2019), Senra (Senra, 2017) and Sinha (2017) which show that there is an influence between celebrity endorsement and sales promotion on perceived quality. This can happen because celebrities who are used as endorsers are able to prove the quality of MSME products in West Java so that the use of celebrity endorsements or influencers in promoting their products is done to attract consumers' interest in purchasing products because they already have the perception that the quality of the products offered is good.

This hypothesis is actually supported by research conducted by Gamliel \& Herstein (2011) which shows that consumers will have more confidence in the quality of a product if the promotion is carried out with a non-celeb endorsement. Shaikh (2017) and Shouman (2020) shows that sales promotion can be a promotional strategy in introducing quality products to consumers, where the research shows that monetary sales promotion plays an important role in the success of the consumer's perceived quality. The test of Between-Subjects Effects of Perceived of Product Risk can be seen on the table below. 
Table 4. Test of Between-Subjects Effects of Perceived of Product Risk (Endorsement).

\begin{tabular}{|c|c|c|c|c|}
\hline \multirow[b]{2}{*}{ PR Endorsement } & \multirow[b]{2}{*}{ Mean } & \multirow[b]{2}{*}{ Std. Error } & \multicolumn{2}{|c|}{$95 \%$ Confidence Interval } \\
\hline & & & Lower Bound & Upper Bound \\
\hline Celeb Endorsement & 3.701 & .031 & 3.641 & 3.762 \\
\hline Non-Celeb Endorsment & 4.650 & .056 & 4.539 & 4.761 \\
\hline
\end{tabular}

Source: Own study.

Table 5. Test of Between-Subjects Effects of Perceived of Product Risk (Sales Promotion)

\section{PR Sales Promotion}

\begin{tabular}{|c|c|c|c|c|}
\hline \multirow{2}{*}{$\begin{array}{l}\text { PR Sales } \\
\text { Promotion }\end{array}$} & \multirow[b]{2}{*}{ Mean } & \multirow[b]{2}{*}{ Std. Error } & \multicolumn{2}{|c|}{ 95\% Confidence Interval } \\
\hline & & & Lower Bound & Upper Bound \\
\hline |Monetary & 4.059 & .057 & 3.946 & 4.171 \\
\hline Non-Monetary & 4.293 & .030 & 4.235 & 4.351 \\
\hline
\end{tabular}

Source: Own study.

Based on the table above, it can be seen that non-celeb endorsement has higher lower bound and upper bound than celebrity endorsement. And non-monetary promotion has higher lower bound and upper bound that monetary sales promotion.

Figure 4. Perceived of Product Risk (Endorsement) Chart.

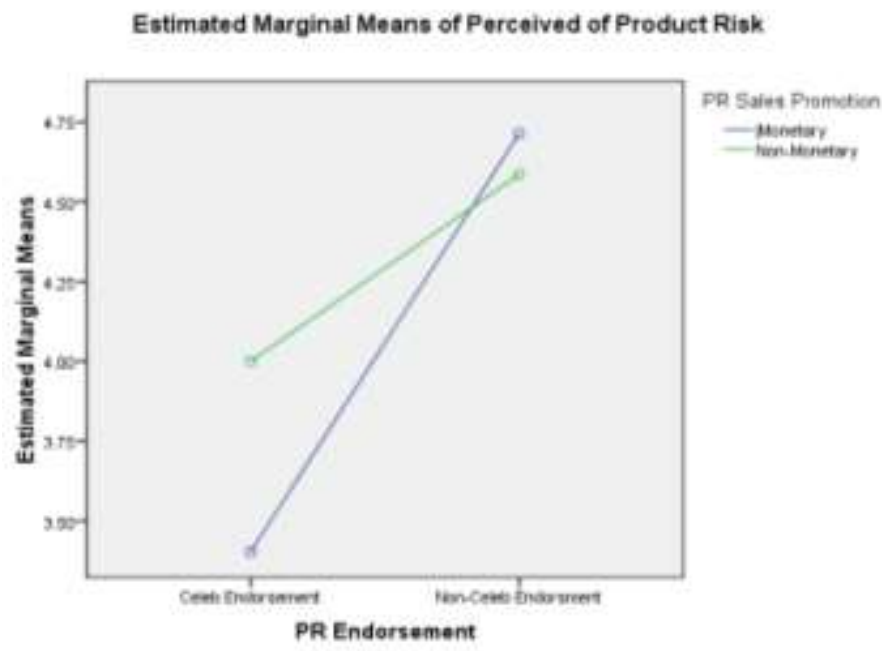

Source: Own study.

Based on the figure above, it can be seen that Participants in the perceived of product risk on celeb endorsements have higher than sales promotion. Participants who receive celeb endorsements have higher perceived of product risk than noncelebrity endorsement (Mceleb= 3,701 and Mnon-celeb= 4,650; $F(1,149)=220,081, p<0,005$ ), while participants of celebrity 
endorsement have higher than non-celeb endorsements (Msalesprom= 4,059 and Mnon-salesprom=4,293; $F(1,149)=13,450$, $\mathrm{p}<0,0005)$.

Two-way Anova was conducted with perceived of product risk as dependent variable and celebrity endorsement (celeb vs non-celeb) and sales promotion (monetary vs non-monetary) as independent variables. This reaffirms the experimental results. The main effect of perceived of product risk is also significant both celebrity endorsement and sales promotion. Thus, the results showed that $\mathrm{H} 2 \mathrm{a}$ was rejected because non-celeb endorsement was higher than celeb endorsement on perceived product risk. As with $\mathrm{H} 2 \mathrm{~b}$, non-monetary sales promotions are higher than monetary sales promotions so that $\mathrm{H} 2 \mathrm{~b}$ is rejected. This means that consumers tend to buy products with non-celebrity endorsements related to product risk perceptions as a marketing strategy for MSME products in West Java. While on sales promotion, consumers tend to prefer non-monetary over monetary on perceived product risk. The results of this study are supported by research conducted by Haron, et al (2013), Farm, et al (2019), Shouman (2020), Shaikh (2017) which shows that there is an influence between celebrity endorsement and sales promotion on product risk perceptions. This can happen because non-celebrities who are used as endorsers are able to prove that MSME products in West Java have minimal risk so that the use of non-celebrity endorsements in promoting their products is done to attract consumers' interest in purchasing products because they already have the perception that promotions carried out by celebrities are products with low risk. In addition, according to Shouman (2020) and Shaikh (2017) sales promotion has an influence on perceived quality and shows that non-monetary sales promotions are considered more as a strategy in marketing that attracts consumer interest.

Table 6. Test of Between-Subjects Effects of Self-Brand Connection (Endorsement)

\section{SB Endorsment}

\begin{tabular}{|c|c|c|c|c|}
\hline \multirow[b]{2}{*}{ SB Endorsment } & \multirow[b]{2}{*}{ Mean } & \multirow[b]{2}{*}{ Std. Error } & \multicolumn{2}{|c|}{ 95\% Confidence Interval } \\
\hline & & & Lower Bound & Upper Bound \\
\hline Celeb Endorsment & 3.925 & .061 & 3.803 & 4.046 \\
\hline Non-Celeb Endorsement & 4.359 & .035 & 4.289 & 4.429 \\
\hline
\end{tabular}

Source: Own study.

Table 7. Test of Between-Subjects Effects of Self-Brand Connection (Sales Promotion)

2. SB Sales Promotion

\begin{tabular}{l} 
Dependent Variable:Self Brand Connection \\
\cline { 4 - 5 } \\
\cline { 4 - 5 }
\end{tabular}

Source: Own study. 
Figure 5. Self Brand Connection.

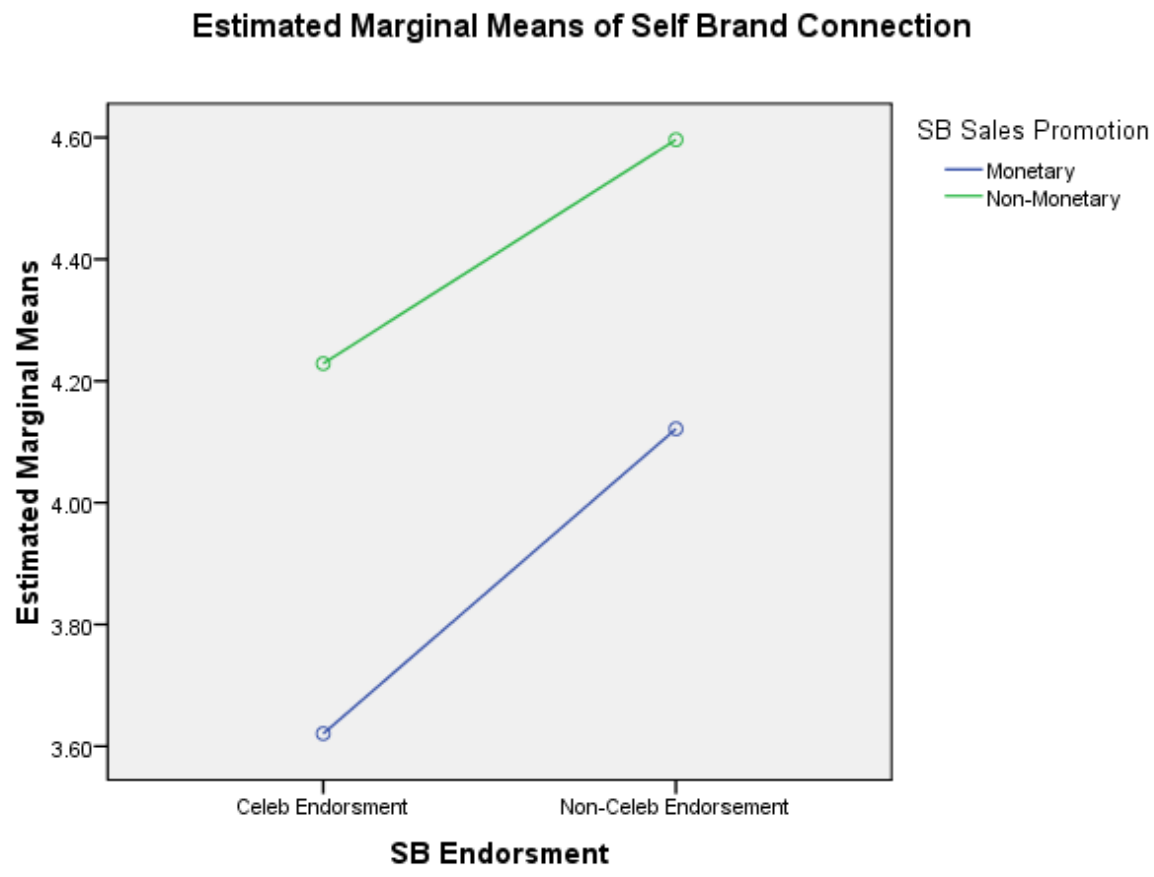

Source: Own study.

Based on the figure above, it can be seen that Participants who receive non-sales promotion have higher self-brand connection than sales promotion (Msalesprom $=3,871$ and Mnon-salesprom $=4,413 ; F(1,149)=58,34, p<0,005$ ) while participants of monetary sales promotion have higher than non-monetary sales promotion (Mceleb=3,925 and Mnon-celeb= 4,359; $\mathrm{F}(1,149)=37,537, \mathrm{p}<0,005)$.

Two-way Anova was conducted with self-brand connection as dependent variable and celebrity endorsement (celeb vs non-celeb) and sales promotion (monetary vs non-monetary) as independent variables. This reaffirms the experimental results. The main effect of self-brand connection is also significant both celebrity endorsement and sales promotion. Thus H3a is rejected, which indicates that consumers tend to buy products with non-monetary sales promotions related to self-brand connection as a marketing strategy for MSME products in West Java.

The results of this study are supported by research conducted by Shaikh (2017), Shouman (2020), Senra (2017), Francis and Yazdanifard (2013) which shows that there is an influence between Celebrity Endorsement and Sales Promotion on Self-Brand Connection, where the research shows that non-celebrity endorsement plays an important role in the success of the consumer's self-brand connection. Based on the results of the study, H3b was also rejected because the self-brand connection on non-monetary sales promotions was higher than monetary sales promotions, so H3b was rejected.

Consumers at SMEs in West Java trust the non-monetary sales promotion strategy more than monetary. This is supported by research conducted by Shaikh (2017), Shouman (2020), Senra (2017), which shows that by using non-monetary sales promotion strategies, it will make consumers have an attachment to products (strong connections) so that the use of nonmonetary sales promotion strategies is carried out to promote their products to attract consumer interest, then they always feel that the product brand is always attached to its use for consumers. 


\section{Conclusions and Suggestions}

\section{Conclusion}

Based on the results of research analysis and discussion of "Brand Strategy Development through sales promotion and endorsement of SMEs in West Java Indonesia". The greatest value between celebrity endorsement and sales promotion on perceived quality is the variable celebrity endorsement with monetary sales promotion.

While for perceived of product risk and self-brand connection non-celebrity endorsement and non-monetary sales promotion are significantly higher. It is shown that many customers believe they would get a good quality of a product if they see celebrity's testimonial, and the eagerness of buying the product will increase if SMEs using monetary sales promotion such as a discount. But, customers will believe they will get lower risk and have higher longevity of the product and because of that trust customer have more self-connection to the brand if non-celebrity such as friend, family or relative suggest them to buy the product and if the product has non-monetary sales promotion.

\section{Suggestion}

Based on the research results, the authors propose several suggestions that can be used for the advancement of MSMEs, especially MSMEs in West Java. For UMKM Business Actors, this research is expected to provide input and suggestions to increase consumer buying interest through increased perceived quality, perceived product risk, and self-brand connections which are influenced by celebrity endorsement and sales promotion.

To improve perceived quality, promotion is needed through monetary sales promotion, such as consumers getting a discount on every purchase of a certain amount, bonus or discount on products for certain purchases. Then to increase the perception of product risk, business actors can increase promotion through monetary sales promotions, which means that business actors can provide discounts, discounts or bonuses to increase consumer perceptions about the risk of the products produced. And finally, to increase the attachment between consumers and a product brand, business actors can use promotions through non-celeb endorsements, namely in the form of advertisements using testimonials from people who have used them before, even though they are not artists, testimonials contain the advantages of the product compared to other products. and the benefits it brings. All of these strategies are expected to provide increased visits and purchases to MSMEs in Indonesia.

\section{Reference}

Alvarez, B., \& Rodolvo, V. (2005). Consumer Evaluations of Sales Promotion: The Effect on Brand Choice. European Journal of Marketing, 39(1/2), 54-70. Bimantari, C. (2019). The Effect of Brand Awareness, Perceived Quality, and Brand Attitude Toward Purchase Intention of Biscuit Oreo in Surabaya. Journal of Business \& Banking, 8(2), 195. https://doi.org/10.14414/jbb.v8i2.1548

Buil, I., Martínez, E., \& de Chernatony, L. (2013). The influence of brand equity on consumer responses. Journal of Consumer Marketing, 30(1), 62-74. https://doi.org/10.1108/07363761311290849

Butter, Oliver, B., Arnd, F., \& Anja, S. (2015). How Shopping Orientation Influences the Effectiveness of Monetary and Non-Monetary Promotions. European Journal of Marketing, 49(1/2), 189.

Chandon, P., Wansink, B., \& Laurent, G. (2000). A Benefit Congruency Framework of Sales Promotion Effectiveness. Journal of Marketing, 64(4), 65-81. https://doi.org/10.1509/jmkg.64.4.65.18071

Chaplin, L., \& John, D. R. (2005). The Development of Self-Brand Connections in Children and Adolescent. Journal of Consumer Research, 32, 119-129. Dwivedi, A. (2015). A higher-order model of consumer brand engagement and its impact on loyalty intentions. Journal of Retailing and Consumer Services, 24, 100-109. https://doi.org/10.1016/j.jretconser.2015.02.007

Escalas, J. (2004). Narrative Processing: Building Consumer Connections to Brands. Journal of Consumer Psychology, 14(1-2), 168-180. https://doi.org/https://doi.org/10.1207/s15327663jcp1401\&2_19

Fam, K.-S., Brito, P. Q., Gadekar, M., Richard, J. E., Jargal, U., \& Liu, W. (2019). Consumer attitude towards sales promotion techniques: a multi-country study. Asia Pacific Journal of Marketing and Logistics, 31(2), 437-463. https://doi.org/10.1108/APJML-01-2018-0005 
Francis, D., \& Rashad, Y. (2013). The Impact of Celebrity Endorsement and Its Influence Through Different Scopes on The Retailing Business Across United States and Asia. International Journal of Commerce, Business and Management (IJCBM), 2(1).

Gamliel, E., \& Herstein, R. (2011). To save or to lose: does framing price promotion affect consumers' purchase intentions? Journal of Consumer Marketing, 28(2), 152-158. https://doi.org/10.1108/07363761111115999

Haron. (2013). Factors Influencing Small Medium Enterprises (SMES) in Obtaining Loan. International Journal of Business and Social Science, 4(15).

Kotler, P., \& Armstrong, G. (2008). Principles of Marketing (12th ed.). Prentice Hall.

Kuo, H.-C., \& Nakhata, C. (2016). Price promotions and products with low consumer ratings. Journal of Consumer Marketing, 33(7), 517-527. https://doi.org/10.1108/JCM-04-2016-1767

Lea-Greenwood, G. (2012). Fashion Marketing Communications E-book. Wiley.

Loucks, E. S., Martens, M. L., \& Cho, C. H. (2010). Engaging small- and medium-sized businesses in sustainability. Sustainability Accounting, Management and Policy Journal, 1(2), 178-200. https://doi.org/10.1108/20408021011089239

Mujahid, N., \& Noman, M. (2018). The Impact of SMEs on the Economic Development of Pakistan. SSRN Electronic Journal. https://doi.org/10.2139/ssrn.3549187

Mussol, S., Aurier, P., \& de Lanauze, G. S. (2019). Developing in-store brand strategies and relational expression through sales promotions. Journal of Retailing and Consumer Services, 47, 241-250. https://doi.org/10.1016/j.jretconser.2018.11.020

Nurcahya, H., \& Majapahit, S. A. (2018). Kajian Penerapan Teknologi Informasi Pada UMKM Sebagai Upaya Memperluas Pasar Produk Lokal. Konferensi Nasional Sistem Informasi, 1365-1369.

Palazon, M., \& Elena, D. (2009). Effectiveness of Price Discounts and Premium Promotions. Psychology \& Marketing, $26(12), 1108-1129$.

Razmus, W., \& Laguna, M. (2019). Brand Engagement in Self-Concept: Scale Properties and the Global Nature of the Construct. Current Psychology, 38(1), 1-7. https://doi.org/10.1007/s12144-017-9584-x

Sarfiah, S., Atmaja, H., \& Verawati, D. (2019). UMKM Sebagai Pilar Membangun Ekonomi Bangsa. Jurnal REP (Riset Ekonomi Pembangunan), 4(2), 1-189. https://doi.org/10.31002/rep.v4i2.1952

Sari, A. M. D., \& Dewi, C. K. (2019). Pengaruh Endorser Credibility terhadap Brand Equity 'Shopee For Men' dengan Self-Brand Connection sebagai Mediator. Jurnal Sekretaris \& Administrasi Bisnis (JSAB), 3(2), 145. https://doi.org/10.31104/jsab.v3i2.123

Schiffman, L. G., \& Kanuk, L. L. (2010). Consumer Behavior 10th Edition. In Pearson Education.

Sedyastuti, K. (2018). Analisis pemberdayaan UMKM dan Peningkatan Daya Saing dalam Kancah Pasar Global. Jurnal Inovasi Bisnis Dan Manajemen Indonesia, 2(1), 117-127.

Senra, A. (2017). The Impact of Monetary and Non-Monetary Promotions on the Brand Equity of New and Mature Products.

Shaikh, F., \& Mazhar, A. (2017). The effectiveness of Social Media Marketing on Consumer Buying Behavior: Study of Small Medium Enterprises.

Shimp, T. (2010). Advertising promotion, and other aspects of integrated marketing communications (8th ed.). South-Western College Publication.

Shouman, L. (2020). The Use of Celebrity Endorsement in Social Media Advertising and its Impact on Online Consumers' Behavior: the Lebanese Scenario. 2020 The 4th International Conference on E-Commerce, E-Business and E-Government, 1-6. https://doi.org/10.1145/3409929.3409930

Sinha, P. R., Kondo, Y., Koike, M., Ogren, J. A., Jefferson, A., Barrett, T. E., Sheesley, R. J., Ohata, S., Moteki, N., Coe, H., Liu, D., Irwin, M., Tunved, P., Quinn, P. K., \& Zhao, Y. (2017). Evaluation of ground-based black carbon measurements by filter-based photometers at two Arctic sites. Journal of Geophysical Research: Atmospheres, 122(6), 3544-3572. https://doi.org/10.1002/2016JD025843

Sudaryanto, R., \& Wijayanti, R. (2014). Strategi pemberdayaan UMKM dalam menghadapi pasar Bebas ASEAN. Jurnal Keuangan \& Moneter. Sugiyono. (2016). Metode Penelitian dan Pengembangan (Research and Development/R\&D). In Bandung: Alfabeta. https://doi.org/10.1016/j.drudis.2010.11.005

Suryani, T. (2013). Perilaku Konsumen di Era Internet: Implikasinya Pada Strategi Pemasaran. Graha Ilmu.

Tjiptono, F., \& Anastasia. (2016). Pemasaran Esesi dan Aplikasi. Andi Offset.

Vaid, N. (2015). Depression in the elderly. InnovAiT: Education and Inspiration for General Practice, 8(9), 555-561. https://doi.org/10.1177/1755738015596030

Valette-Florence, P., Guizani, H., \& Merunka, D. (2011). The impact of brand personality and sales promotions on brand equity. Journal of Business Research, 64(1), 24-28. https://doi.org/10.1016/j.jbusres.2009.09.015

Vijayasarathy, L. R., \& Jones, J. M. (2000). Print and Internet catalog shopping: assessing attitudes and intentions. Internet Research, 10(3), 191-202. https://doi.org/10.1108/10662240010331948

Yi, Y., \& Yoo, J. (2011). The long-term effects of sales promotions on brand attitude across monetary and non-monetary promotions. Psychology \& Marketing, 28(9), 879-896. https://doi.org/10.1002/mar.20416 